\title{
The effect of selenium administration on the growth and health of sheep on Scottish farms
}

\author{
BY K. L. BLAXTER \\ Hannah Dairy Research Institute, Kirkhill, Ayr \\ (On behalf of an Agricultural Research Council Working Party on Selenium)
}

(Received I I May Ig62)

The experiments reported involved the collaboration of over fifty people. The experiments were planned, organized and interpreted by a working party, on which, at the invitation of the Agricultural Research Council, the following served:

K. L. Blaxter, Hannah Dairy Research Institute, Kirkhill, Ayr.

E. J. Butler, Moredun Institute, Gilmerton, Edinburgh.

D. J. Finney, ARC Unit of Statistics, University of Aberdeen.

C. F. Mills, Rowett Research Institute, Bucksburn, Aberdeen.

R. L. Mitchell, Macaulay Institute for Soil Research, Craigiebuckler, Aberdeen.

G. A. M. Sharman, North of Scotland College of Agriculture, Mill of Craibstone, Aberdeen.

The field investigations were undertaken by the three Agricultural Colleges in Scotland. Their immediate supervision was organized in the Veterinary Investigation Departments of the three colleges by:

A. L. Wilson and J. M. Robertson, West of Scotland Agricultural College, Ayr.

L. G. Donald and G. A. M. Sharman, North of Scotland College of Agriculture, Aberdeen.

J. A. Watt and T. B. Nicolson, Edinburgh and East of Scotland College of Agriculture, Edinburgh.

The selection of farms and the collection of experimental records were undertaken by the Assistant Veterinary Investigation Officers and the Agricultural Advisory Officers of the colleges. Those concerned were:

\section{West area}
C. C. Bannatyne
G. M. Berrie
A. Broadfoot
I. A. Dickson
R. N. Gentles
A. W. Baillie
W. A. Buckpitt
H. H. Corner
T. B. Dickson
D. A. Hughes
W. S. Johnson
A. Macleod
A. G. Malcolm
I. W. Mitchell
R. Rowat
R. M. Patterson
S. A. Ross
J. Thorburn
J. Waddell
C. C. Watson

\section{East area}

T. Johnston

C. J. H. McCulloch

J. C. F. McIntyre

C. G. Mackenzie

I. McLaughlin

N. S. M. Macleod
C. M. Robertson
R. F. Thow
N. Turner
H. J. Usher
J. N. Watson
A. Wynd 


\begin{tabular}{lll}
\multicolumn{3}{c}{ North area } \\
C. M. Allan & A. Howie & W. J. S. Merchant \\
D. R. Bissett & J. K. McGillivray & R. W. Warren \\
M. E. Daw & J. M. Maddox & G. Watt \\
G. D. Findlay & A. Martin & G. S. Ziffo \\
W. J. Guthrie & &
\end{tabular}

The work of Patterson, Milstrey \& Stokstad (1957) and of Schwarz \& Foltz (1957) first established the existence of a relation between selenium and vitamin $E$ in the prevention of exudative diathesis in chicks and necrotic liver degeneration in mice and rats. Many investigations have since been made to find whether Se administration will prevent other nutritional disorders in which vitamin $\mathrm{E}$ deficiency is involved, particularly those of economic importance in livestock husbandry. Thus Proctor, Hogue \& Warner (1958), at Cornell, found that the addition of I p.p.m. Se to the diet of ewes was as effective as $\alpha$-tocopherol in preventing the occurrence of muscular dystrophy in lambs. In Oregon, Muth and his collaborators (Muth, Oldfield, Remmert \& Schubert, r958; Muth, Oldfield, Schubert \& Remmert, 1959) showed that the addition of $0 \cdot I$ p.p.m. Se to diets of Ladino clover and lucerne hay afforded lambs almost complete protection against muscular dystrophy. In New Zealand, congenital muscular dystrophy was better controlled by the oral administration of Se during pregnancy than by dietary supplements of vitamin E (Drake, Grant \& Hartley, I $960 a$ ), and a similar result was obtained in comparisons of the effects of Se and vitamin $\mathrm{E}$ administration to lambs in areas where delayed muscular dystrophy is common (Drake et al. 1960b). In Scotland Se and vitamin $\mathrm{E}$ were found equally effective in preventing an enzootic muscular dystrophy of calves which occurred in the Moray Firth area (Sharman, Blaxter \& Wilson, 1959; Blaxter, McCallum, Wilson, Sharman \& Donald, 1961).

During experiments with Se in New Zealand, it was noted that on many farms on which clinical cases of muscular dystrophy occurred, and also on some on which it was absent, Se administration resulted in increased weight gain of lambs and young sheep (McLean, Thompson \& Claxton, 1959). These increases in weight were spectacular on those holdings on which lambs normally failed to thrive (Jolly, I960; Drake et al. $1960 b$ ), so much so that it seemed that much of the "hoggett ill thrift syndrome' (Clarke \& Filmer, 1958) could be ascribed to Se deficiency. Hartley \& Grant (196I) in reviewing the New Zealand work have used the term 'selenium responsive unthriftiness' to describe these animals; they state that it is evident that this unthriftiness is distinct from a type of unthriftiness occurring on autumn pastures, and infer that the hoggett ill thrift syndrome is not simply a Se deficiency.

The presence of enzootic muscular dystrophy in cattle in Scotland and the fact that it responds to Se administration, together with the New Zealand evidence that in areas where muscular dystrophy occurs the weight gain of sheep can be enhanced by Se administration, prompted the experiments described below. They were carried out on a large scale so that if any deficiency was detected an estimate could be made of its importance in the sheep-farming economy of Scotland. 


\section{EXPER I MEN T AL}

Experiments with wintered sheep. Trials were made with 8 i 1 sheep of hill breeds on ten farms in the Moray Firth area where muscular dystrophy in cattle occurs. Their object was to find whether Se as sodium selenate given by injection at monthly or at fortnightly intervals increased the weight gain of sheep during the winter period. Because some of the flocks were on land presumed to be cobalt-deficient and because McLean et al. (1959) had found a synergistic effect of Se and Co in some of their trials in New Zealand, Co was administered to half the flock as an additional treatment. Co was given as a 'bullet' (Aspro-Nicholas Ltd) at the beginning of the trials on some farms. The experimental treatments were:

(1) One Co bullet; $3 \mathrm{mg}$ Se given at monthly intervals.

(2) One Co bullet; $3 \mathrm{mg}$ Se given at fortnightly intervals.

(3) $3 \mathrm{mg}$ Se given at monthly intervals.

(4) $3 \mathrm{mg}$ Se given at fortnightly intervals.

(5) One Co bullet.

(6) No treatment.

On three farms all six treatments were given, on four farms treatments I, 3, 4 and 5 , on two farms treatments $I$ and 5 only and on one farm treatments 1,2 and 5 only. The sheep were allocated to treatment at random. The trials lasted for the 4-5 winter months and the sheep were weighed at monthly intervals.

Experiments with lambs. The main experiments were carried out on seventy-six farms. These farms were selected in such a way that they were distributed over the major geological formations in Scotland, with a deliberately small preponderance given to flocks on soils derived from the Old Red Sandstone. Their distribution is given in Fig. I. The selection was made locally and independently of the final classification of farms into geological groups.

On each farm about sixty lambs were identified by ear tags; the sex of each was recorded and each was allocated at random to one of two treatments:

(a) $3 \mathrm{mg}$ Se as selenate by subcutaneous injection at approximately 4-week intervals;

(b) no treatment.

When twins occurred, one was allocated to each treatment. In addition, on eighteen of the farms where there was some reason to believe that Co deficiency might occur, half the lambs in each group were given Co as a bullet at the beginning of the experiment. The number of lambs included in the experiment was 4448 .

Each lamb was weighed at the time injections were given and any deaths or illnesses that had occurred in the preceding weeks were recorded.

The Se solution used in both trials was prepared in bulk under sterile conditions, preserved with phenol and dispensed in sealed bottles. Before issue it was given to adult sheep and calves by subcutaneous injection in amounts which per kg bodyweight were twice those subsequently employed in the field. No toxic effects were found.

Farm classification in the lamb experiments. There is no specific information on the Se content of Scottish soils and little information about the pedological behaviour of 
Se. Geochemical and crystallochemical evidence (Goldschmidt, 1954; Rankama \& Sahama, 1950) shows, however, that the Se content of rock varies with the sulphur content, the ratio of $S$ to $S e$ being in the range 4000:I to 7000:1. Because the $S$ content of the parent material of soils normally varies from 300 p.p.m. in sandstones and 500 p.p.m. in granites to 2600 p.p.m. in shales, the Se content may be expected

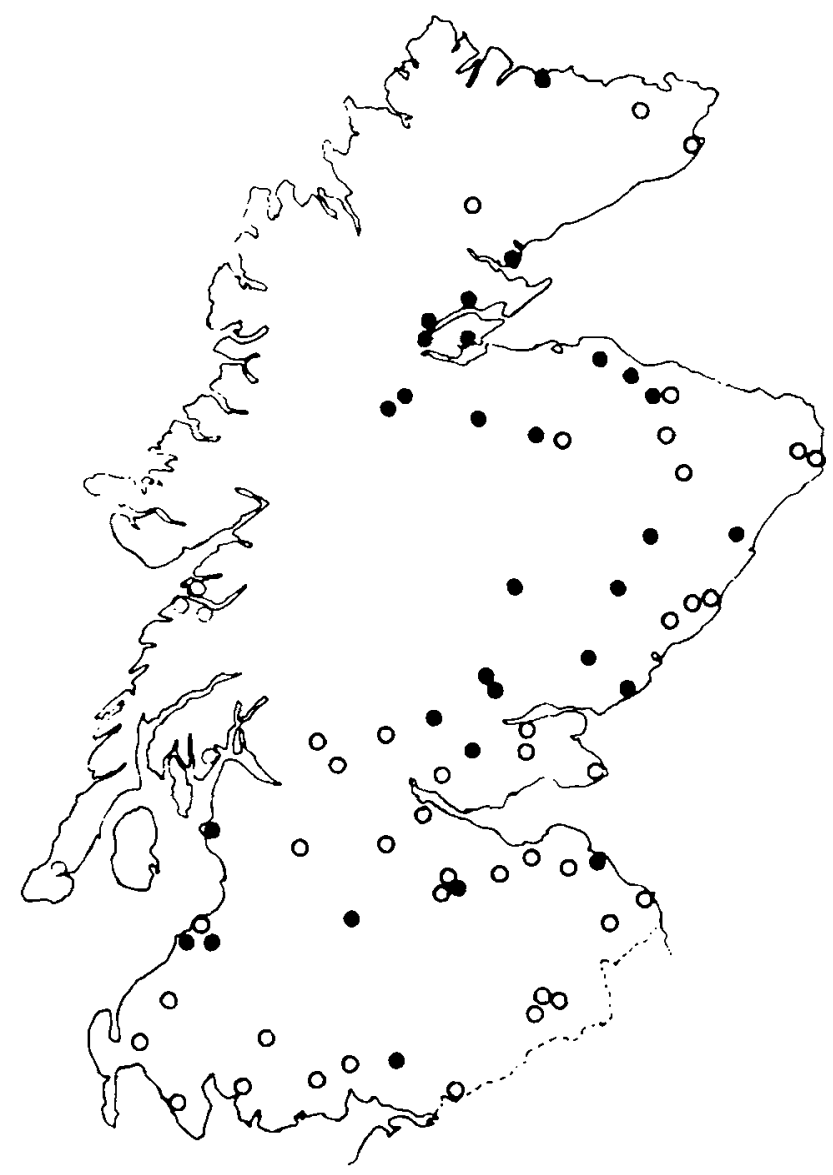

Fig. 1. Distribution of the seventy-six farms that collaborated in the lamb experiment. -, farms in soil class $1 ; O$, farms in soil classes $2-6$ (see below).

to be highest in those soils derived from shales, gabbros and basic igneous rocks and lowest in those derived from arenaceous Old Red Sandstone and Carboniferous Limestone rocks. The farms were therefore classified on this broad basis into six parent material groups which in ascending order of presumptive Se content were:
(I) Arenaceous
(2) Acid igneous
(3) Calcareous
(4) Mixed: 4-, possibly biased to low Se; $4+$, possibly biased to high Se
(5) Basic igneous
(6) Argillaceous 
About half the farms had been surveyed by the members of the Soil Survey of Scotland based at the Macaulay Institute for Soil Research, and on these farms there was little difficulty in classification. For the remainder, classification had to be based on maps of the underlying geological formations and, when pertinent, the drift geology of the area. None of the farms fell in group 3.

Statistical analysis. Collection of records was facilitated by providing a printed recording book for each farm. From these original records the increment in weight of each lamb during the whole trial of 3-4 months was obtained, and these were analysed statistically. The weight gains derived from intermediate weighings were also examined to see if they would provide additional information. The results for any lamb which was absent from any one of the monthly gatherings and hence was not given its injection of Se were discarded in this analysis.

\section{RESULTS}

Preliminary trial with wintered sheep. The responses to dosage with Se on each of the ten farms are given in Table $\mathrm{r}$. These are the differences between the mean weight gains of the experimental and control groups and apply to the whole period of the trials. On those farms on which the sheep were dosed monthly or fortnightly the mean response to $\mathrm{Se}$ is given. These mean responses varied from $-\mathrm{r} \cdot 8$ to $+5 \cdot 0 \mathrm{lb} /$ sheep and six were statistically significant. The overall mean response to Se of $+2.3 \pm 0.6 \mathrm{lb} / \mathrm{sheep}$ was also statistically significant $(P<0.01)$. Examination of the responses to monthly and fortnightly dosing with Se on four farms showed that fortnightly dosing produced a response $\mathrm{I} \cdot 8 \pm \mathrm{I} \cdot \mathrm{Olb}$ greater than did monthly dosing, a difference that was scarcely significant statistically. It was concluded that regular dosing with $\mathrm{Se}$ increased the weight of sheep by about $2 \mathrm{lb} / \mathrm{head}$, a figure which might rise to $4 \mathrm{lb} /$ head with fortnightly dosing. Evidently responses to Se varied from farm to farm, and even more striking was the considerable variation from farm to farm in the gains made by the controls during the winter period.

Table I. Response (mean values with their standard errors) of wintered sheep on ten farms to the monthly injection of selenium

\begin{tabular}{|c|c|c|c|}
\hline Farm reference & $\begin{array}{l}\text { Length of period } \\
\text { (days) }\end{array}$ & $\begin{array}{l}\text { Change in weight } \\
\text { of controls } \\
\text { (lb) }\end{array}$ & $\begin{array}{l}\text { Response to selenium } \\
\text { (lb) }\end{array}$ \\
\hline Art & 154 & $19 \cdot 1$ & $-0.4 \pm 1 \cdot 3$ \\
\hline Du & 168 & $-7 \cdot 2$ & $1 \cdot 2 \pm 1 \cdot 2$ \\
\hline $\mathrm{Ga}$ & 154 & $-4 \cdot 3$ & $2.9 * \pm 1.4$ \\
\hline All & 160 & $5 \cdot 4$ & $8 \cdot 8 * \pm 2 \cdot 3$ \\
\hline $\mathrm{Be}$ & 154 & $24 \cdot 2$ & $-1 \cdot 8 \pm 2 \cdot 8$ \\
\hline $\mathrm{Br}$ & Iro & $9 \cdot 0$ & $4.4^{*} \pm 2.2$ \\
\hline $\mathrm{Cl}$ & 169 & $-7 \cdot 7$ & $2 \cdot 0^{*} \pm 1 \cdot 0$ \\
\hline Ard & 171 & $35 \cdot I$ & $-r \cdot 4 \pm r \cdot 8$ \\
\hline W.L. & 158 & 6.6 & $5 \cdot 0^{*} \pm 1 \cdot 8$ \\
\hline Le & 167 & $-7 \cdot I$ & $2 \cdot 7^{*} \pm 1 \cdot 2$ \\
\hline General mean & - & - & $\pm 2.3 \pm 0.6$ \\
\hline
\end{tabular}


On the seven farms on which it was tested the mean response to Cowas $+1 \cdot 0 \pm 0 \cdot 7 \mathrm{lb} /$ sheep, which was not statistically significant. No differences in the response to Se or to Co could be attributed to any subclassification of the animals according to sex or breed, nor was any differential morbidity evident.

Experiments with lambs. Not all the 4448 lambs initially included in the experiment were included in the final analysis. Some were recorded as having died, some were sold, some were reported as missing presumed dead, and some were absent from one or more gatherings of the flock between the initial and final weighings. From these incidental losses of experimental animals, summarized in Table 2, the conclusion was drawn that Se injections did not affect the known mortality rate of the lambs, which in these trials was about $1 \%$.

Table 2. Losses of lambs in the experiments

$\begin{array}{lcc}\text { Controls } & \begin{array}{c}\text { Lambs given } \\ \text { selenium }\end{array} \\ \begin{array}{l}\text { No. at beginning } \\ \text { of experiment }\end{array} & 2224 & 2224 \\ \text { No. sold } & 23 & \\ \text { No. died } & 21 & 23 \\ \text { No. missing } & 35 & 21 \\ \text { Other losses* } & 133 & 35 \\ & & 122\end{array}$

* Includes all unexplained disappearances from the records for one or more gatherings during the experimental period.

Analysis of the weight gains of the remaining lambs during the whole trial showed no consistent effect of sex on the response of lambs to Se or any interaction between the effect of Se and that of Co. Table 3 gives the results of each of the seventy-six experiments, expressed in terms of responses to Se administration, together with the geological classification of the farm. The responses on individual farms varied from $+5.8 \mathrm{lb} / \mathrm{lamb}$ to $-4.7 \mathrm{lb} / \mathrm{lamb}$; standard errors of these responses calculated from variation between lambs treated alike averaged $\pm \mathrm{I} \cdot 7 \mathrm{I} \mathrm{lb} / \mathrm{lamb}$, and few responses were individually significant at the $5 \%$ level. The unweighted mean of all the seventysix responses was $0.8 \mathrm{I} \mathrm{lb} / \mathrm{lamb}$; although this value is statistically significant, the response on any one farm appears to have depended considerably upon soil, as is discussed below.

Table 4 summarizes the responses averaged according to their geological classification and the standard errors of their means. These standard errors were based on responses differing from farm to farm within a geological group; the appropriate value to compare with the standard error of $\pm \mathrm{I} \cdot 7 \mathrm{I} \mathrm{lb} /$ lamb quoted above is $\pm 1 \cdot 76 \mathrm{lb} /$ lamb, which suggests that variation in response within a geological group was largely due to inter-animal variation rather than to real variation in response from farm to farm.

Table 4 shows that responses to Se were highest on those farms situated on soils with the lowest presumptive Se content, and that a general trend toward low or negative response occurred on soils with a high presumptive Se content. When the more precise information of the soil survey was used to classify the farms, the contrast 
Vol. I7

Table 3. Mean response of lambs to selenium injection on seventy-six farms

\begin{tabular}{|c|c|c|c|c|}
\hline \multirow[b]{2}{*}{ Farm no. } & \multirow[b]{2}{*}{$\begin{array}{c}\text { Soil } \\
\text { classification } \dagger\end{array}$} & \multirow[b]{2}{*}{$\begin{array}{l}\text { Period } \\
\text { (days) }\end{array}$} & \\
\hline & & & lb/lamb & $\begin{array}{c}\text { (lb/lamb day) } \\
\times 1 \infty\end{array}$ \\
\hline $\begin{array}{l}x \\
2\end{array}$ & $\begin{array}{l}2 \\
6\end{array}$ & $\begin{array}{l}85 \\
88\end{array}$ & $\begin{array}{r}1.56 \\
-1.58\end{array}$ & $\begin{array}{r}I .84 \\
-1.80\end{array}$ \\
\hline 3 & 2 & 79 & -0.40 & $-0.5 I$ \\
\hline $4(s)$ & 6 & 80 & 0.70 & 0.88 \\
\hline 5 & 5 & 82 & 0.80 & 0.98 \\
\hline 6 & I & 86 & $1 \cdot 14$ & $\mathbf{I} \cdot 33$ \\
\hline 7 & $4+$ & 69 & -0.31 & -0.45 \\
\hline 8 & 6 & 96 & $-1 \cdot 12$ & $-1 \cdot 17$ \\
\hline 9 & I & 96 & $4 \cdot 49$ & $4 \cdot 68$ \\
\hline 10 & $4+$ & 77 & $-1 \cdot 57$ & -2.04 \\
\hline II & 4- & 87 & -0.90 & $-1 \cdot 03$ \\
\hline 12 & $4-$ & 102 & 3.54 & 3.47 \\
\hline $13(\mathrm{~s})$ & 6 & 90 & $-1 \cdot 35$ & 1.50 \\
\hline 14 & 1 & 90 & $\mathrm{I} \cdot 85$ & 2.06 \\
\hline 15 & 6 & 62 & -0.14 & -0.23 \\
\hline 16 & 6 & IOI & $-2 \cdot 60$ & -2.57 \\
\hline $17(\mathrm{~s})$ & 5 & 53 & -0.39 & -0.74 \\
\hline $18(s)$ & 1 & III & $I \cdot 42$ & I.28 \\
\hline $19(\mathrm{~s})$ & I & I 13 & 2.57 & $2 \cdot 27$ \\
\hline $20(s)$ & $4-$ & 86 & $2 \cdot 20$ & $2 \cdot 56$ \\
\hline 2 I $(s)$ & 6 & 87 & $-1 \cdot 76$ & -2.02 \\
\hline $22(s)$ & I & 87 & $-x \cdot 67$ & $-1 \cdot 92$ \\
\hline 23 & 4 & IOI & 0.56 & 0.55 \\
\hline 24 & $4+$ & NK & $-I \cdot I I$ & $-1 \cdot 23$ \\
\hline 25 & 4 & NK & I.59 & 1.77 \\
\hline 26 & $4+$ & 77 & 0.68 & 0.88 \\
\hline 27 & $4+$ & 57 & 3.29 & 5777 \\
\hline 28 & $4-$ & 101 & -0.14 & -0.14 \\
\hline 29 & I & 94 & 3.33 & 3.54 \\
\hline 30 & I & 97 & $2 \cdot 03$ & 2.09 \\
\hline $31(8)$ & I & 92 & 0.65 & 0.71 \\
\hline $32(s)$ & I & 96 & 3.70 & $3 \cdot 85$ \\
\hline 33 & I & $9 \mathrm{I}$ & $1 \cdot 51$ & 1.66 \\
\hline 34 & $\mathbf{r}$ & $9 \mathrm{I}$ & $I \cdot 6 I$ & $1 \cdot 77$ \\
\hline 35 & $x$ & 91 & 2.82 & $3 \cdot 10$ \\
\hline 36 & I & 99 & 0.97 & 0.98 \\
\hline 37 & I & 101 & -0.68 & -0.67 \\
\hline $38(s)$ & I & II7 & 4.03 & 3.44 \\
\hline 39 & $x$ & 87 & -0.12 & -0.14 \\
\hline $40(\mathrm{~s})$ & $x$ & 89 & I'II & $3 \cdot 25$ \\
\hline $41(s)$ & 6 & 85 & 0.43 & 0.51 \\
\hline $42(s)$ & 4 & 61 & -2.93 & -4.80 \\
\hline $43(s)$ & 4 & 119 & $2 \cdot 10$ & 1.76 \\
\hline $44(s)$ & 5 & 63 & $1 \cdot 22$ & $1 \cdot 94$ \\
\hline $45(s)$ & 5 & 70 & $2 \cdot I I$ & 3.01 \\
\hline 46 & $4+$ & 89 & 0.57 & 0.64 \\
\hline 47 & I & 77 & 3.07 & 3.99 \\
\hline 48 & $4+$ & 63 & I'I 6 & $\mathrm{I} \cdot 84$ \\
\hline 49 (s) & $4+$ & 91 & -4.73 & -520 \\
\hline & & 100 & & \\
\hline
\end{tabular}


Table 3 (cont.)

\begin{tabular}{|c|c|c|c|c|}
\hline \multirow[b]{2}{*}{ Farm no. } & \multirow{2}{*}{$\begin{array}{l}\text { Soil } \\
\text { classifica- } \\
\text { tiont }\end{array}$} & \multirow[b]{2}{*}{$\begin{array}{l}\text { Period } \\
\text { (days) }\end{array}$} & \multicolumn{2}{|c|}{ Mean response } \\
\hline & & & $\mathrm{lb} / \mathrm{lamb}$ & $\begin{array}{c}\text { (lb/lamb day) } \\
\times 100\end{array}$ \\
\hline $51(s)$ & I & 100 & 3.68 & 3.68 \\
\hline $52(s)$ & 6 & 109 & $-1 \cdot 79$ & $-1 \cdot 64$ \\
\hline 53 & 6 & $5^{8}$ & $-I \cdot 16$ & $-2 \cdot 00$ \\
\hline 54 & $\mathbf{I}$ & 84 & $-3 \cdot 16$ & $-3 \cdot 76$ \\
\hline $55(s)$ & $4-$ & 87 & $-2 \cdot 07$ & $-2 \cdot 38$ \\
\hline $56(s)$ & $\mathbf{I}$ & 77 & $5 \cdot 77$ & $7 \cdot 49$ \\
\hline $57(\mathrm{~s})$ & $\mathbf{I}$ & 71 & $1 \cdot 97$ & $2 \cdot 77$ \\
\hline $5^{8}(\mathrm{~s})$ & I & 70 & 0.00 & 0.00 \\
\hline 59 & I & 60 & $\mathbf{2} \cdot \mathbf{2} 8$ & $3 \cdot 80$ \\
\hline 60 & $4+$ & 103 & $r \cdot 67$ & $I \cdot 62$ \\
\hline $61(s)$ & I & 74 & $2 \cdot 71$ & 3.66 \\
\hline 62 & $\mathbf{I}$ & 56 & -0.24 & -0.43 \\
\hline $63(s)$ & $\mathbf{I}$ & 78 & $2 \cdot 68$ & $3 \cdot 44$ \\
\hline 64 & $4-$ & 114 & $3 \cdot 73$ & $3 \cdot 27$ \\
\hline $65(s)$ & 1 & 120 & $2 \cdot 04$ & $1 \cdot 70$ \\
\hline $66(s)$ & 4 & 84 & -0.97 & $-I \cdot I 5$ \\
\hline $67(s)$ & 4 & 88 & 0.98 & I.II \\
\hline 68 (s) & I & 119 & 0.49 & $0.4 I$ \\
\hline $69(\mathrm{~s})$ & 5 & 83 & 0.36 & 0.43 \\
\hline $70(s)$ & 6 & 84 & $1 \cdot 03$ & 1.23 \\
\hline $71(s)$ & $4+$ & 77 & $1 \cdot 10$ & 1.43 \\
\hline $72(s)$ & 4 & 78 & $1 \cdot 18$ & $1 \cdot 51$ \\
\hline $73(s)$ & 6 & 63 & 0.28 & 0.44 \\
\hline 74 & $4-$ & 85 & $1 \cdot 17$ & $1 \cdot 38$ \\
\hline $75(s)$ & I & 87 & $1 \cdot 3^{6}$ & I. 56 \\
\hline $76(\mathrm{~s})$ & 4 & 82 & $-0.2 \mathrm{I}$ & -0.26 \\
\hline
\end{tabular}

NK, not known precisely, but approximately 3 months.

- (s) indicates the farm had been surveyed by the Scottish Soil Survey

$\uparrow$ See p. 108 ; ascending order of presumptive Se content, $I-6$.

Table 4. Mean response of lambs to selenium injection, classified according to the presumptive Se content of the soil

\begin{tabular}{|c|c|c|c|c|}
\hline \multirow{2}{*}{$\begin{array}{c}\text { Soil } \\
\text { classi- } \\
\text { fication* }\end{array}$} & \multicolumn{2}{|c|}{ All farms } & \multicolumn{2}{|c|}{$\begin{array}{l}\text { Farms surveyed by the } \\
\text { Scottish Soil Survey }\end{array}$} \\
\hline & $\begin{array}{l}\text { No. of } \\
\text { farms }\end{array}$ & $\begin{array}{l}\text { Response } \\
\text { (lb/lamb) }\end{array}$ & $\begin{array}{l}\text { No. of } \\
\text { farms }\end{array}$ & $\begin{array}{l}\text { Response } \\
\text { (lb/lamb) }\end{array}$ \\
\hline I & 31 & $I \cdot 72 \pm 0.32$ & 16 & $2.03 \pm 0.44$ \\
\hline 2 & 2 & $0.58 \pm 1.24$ & 0 & - \\
\hline $4^{-}$ & 7 & $I .08 \pm 0.67$ & 2 & $0.06 \pm 1.24$ \\
\hline 4 & 9 & $0.38 \pm 0.59$ & 6 & $0.02 \pm 0.72$ \\
\hline $4+$ & 10 & $0.08 \pm 0.56$ & 2 & $-1 \cdot 82 \pm 1.24$ \\
\hline 5 & 5 & $0.82 \pm 0.79$ & 4 & $0.82 \pm 0.88$ \\
\hline 6 & 12 & $-0.76 \pm 0.51$ & 7 & $-0.35 \pm 0.67$ \\
\hline $4+, 5,6$ & 27 & $-0.16 \pm 0.34$ & 13 & $-0.21 \pm 0.48$ \\
\hline All & 76 & 0.81 & 37 & $0.8 \mathrm{I}$ \\
\hline
\end{tabular}

- See p. 108 ; ascending order of presumptive Se content, $1-6$. 
between responses to Se on farms with soil of low and of high Se content was even more marked. It would appear that responses of $2 \mathrm{lb} / \mathrm{lamb}$ may be expected on farms on soils of low presumptive Se content. Fig. 2 shows the results, expressed as frequency distributions, for group $I$ and for groups $4+, 5$ and 6 . It shows that considerable variation in response occurred.

The possibility that the main benefit from Se might occur early in the experiment was examined by comparing the gains of the two groups during the ist month of the experiment. The mean response to Se was $0.09 \mathrm{lb} / \mathrm{lamb}$. The response on the thirtyone farms in geological group I was $+0.32 \mathrm{lb}$, and on the twenty-seven farms in geological groups $4+, 5$ and $6,-0.07 \mathrm{lb} / \mathrm{lamb}$. These results suggest that the response to Se administration was a progressive one, and was not due to an initial acceleration of weight gain.

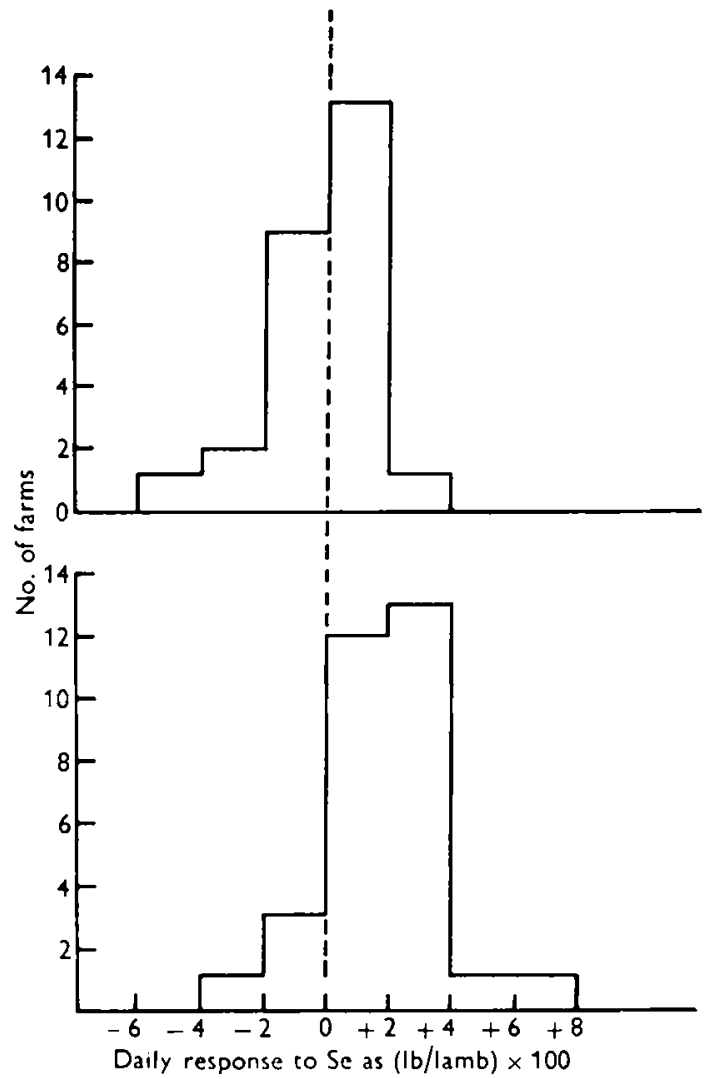

Fig. 2. Frequency distributions of the response in weight gain of lambs to selenium injection on farms in soil class I (low presumptive content of Se) (lower) and in soil classes $4+, 5$ and 6 (high presumptive content of Se) (upper).

\section{DISCUSSION}

The results of these trials show that, on farms with soil derived from arenaceous sands of the Old Red Sandstone or similar material, increases in the gain in weight of lambs and of wintered sheep $6-9$ months of age occurred after Se administration. 
On farms where the presumptive Se content of the soil was high, there was no response to Se.

In Scotland the highest incidence of muscular dystrophy in cattle occurs on farms situated around the Moray Firth, Aberdeenshire and Perthshire, where it appears to be associated with soils derived from arenaceous sands of the Old Red Sandstone (Sharman et al. 1959; Blaxter et al. 1961). The results of these experiments with cattle and of the trials reported here suggest very strongly that the Se content of pasture herbage and crops grown on soils so derived is low. From the information now available, it would appear that about one-tenth of the land area of Scotland, i.e. about 2 million acres, carries soils that would be classified as group I, and therefore possibly of low Se content. Much of this area consists of very rough hill grazing or deer forest and, from the soil surveys so far completed, the total area of arable land in group I is probably under 250 thousand acres (400 square miles).

The growth responses to Se obtained in New Zealand have been summarized by Hartley \& Grant (1961). In many New Zealand experiments the increases in weight gains after dosing with Se determined over periods of 3-4 months were more than Io $\mathrm{lb} / \mathrm{lamb}$, whereas those we observed on farms in Scotland with a low presumptive soil content of Se were $2 \mathrm{lb} / \mathrm{lamb}$. In Oregon, USA, Se administration for a 6-week period increased weight gains by $6 \mathrm{lb} / \mathrm{lamb}$ (Schubert, Muth, Oldfield \& Remmert, 1961) which again is considerably greater than the gains we have observed in 3-4 month periods. In most New Zealand experiments and in those Oregon experiments that have been reported, Se administration reduced the mortality and morbidity of lambs due to muscular dystrophy. In our experiments there was no differential mortality, and no clinical evidence of muscular dystrophy was recorded in any animal. Muscular dystrophy has only been recorded in sheep in Scotland as a clinical entity on two occasions (Marr, Sharman \& Blaxter, 1956; Nisbet, Butler \& Macintyre, 1959), but Stamp's (1960) studies suggest that the disease may be widespread and to a large extent undiagnosed, particularly in newborn lambs. The above evidence suggests that the Se deficiency which exists on soils derived from the Old Red Sandstone and certain granites is less severe than that which occurs on the stoney soils of the South Island of New Zealand, the pumice soils of the North Island of New Zealand or in certain areas of Oregon, USA.

Increases in the growth rate of lambs and of wintered sheep of the magnitude we have observed, namely, about $2 \mathrm{lb} / \mathrm{sheep}$, are economically worth while if they can be obtained at little expense and with no risk. Though the cost of the $9 \mathrm{mg}$ Se used to treat one lamb by injection is negligible, the cost of the labour involved is large. This cost could be reduced either by giving Se mixed with supplementary food or by the application of Se to the soil. Calculations indicate that the application to the land of $5 \mathrm{~g} \mathrm{Se} / \mathrm{acre}$ or the addition of $500 \mathrm{mg}$ Se to every ton of food would correct the deficiency. Se is a very toxic element, however; the margin of safety between the amounts of Se we have given and those which would give rise to toxic effects has not been precisely determined, but is probably small. C. F. Mills (1962, unpublished observations), for example, has found that, when pregnant Blackface ewes were given $30 \mathrm{mg}$ Se by subcutaneous injection during the winter, death occurred within $24 \mathrm{~h}$. 
In the commercial application of these findings, errors in the fortification with Se of foods or fertilizers or accidental local concentrations resulting from such fortification could thus constitute a serious risk.

\section{SUMMARY}

I. In experiments on ten farms with 8 I I sheep, the effect of selenium given by subcutaneous injection as sodium selenate was studied. Dosing at 2-week intervals significantly increased weight gains by about 2-4 lb/sheep during the winter period of 4-5 months. There was no significant response to administration of cobalt and no indication of a synergism.

2. In trials on seventy-six farms with $444^{8}$ lambs, $3 \mathrm{mg}$ Se were given by subcutaneous injection at approximately 4-week intervals to half the lambs on each farm. The farms were classified into groups according to the presumptive Se content of the soil.

3. In the whole experiment dosing with Se increased weight gain by $0.8 \mathrm{lb} / \mathrm{lamb}$.

4. On thirty-one farms situated on soils with the lowest presumptive Se content, the mean response to Se was $1 \cdot 7 \pm 0.32 \mathrm{lb} / \mathrm{lamb}$ and on twenty-seven farms with the highest presumptive Se content it was $-0.16 \pm 0.34 \mathrm{lb} / \mathrm{lamb}$.

5. It is concluded that about one-tenth of the land area of Scotland is mildly deficient in Se. Much of it is rough hill grazing and the total arable area involved is probably under 250000 acres.

6. It is pointed out that the Se deficiency in Scottish soils is less severe than that recorded in New Zealand or Oregon, USA. In view of the toxicity of Se practical remedial measures involve an element of risk.

The Working Party wishes to thank the flock-masters and their shepherds for their collaboration, interest and help.

\section{REFERENCES}

Blaxter, K. L., McCallum, E. S. R., Wilson, R. S., Sharman, G. A. M. \& Donald, L. G. (I96I). Proc. Nutr. Soc. 20, vi.

Clarke, E. A. \& Filmer, D. B. (1958). N.Z. F. agric. Res. 1, 249.

Drake, C., Grant, A. B. \& Hartley, W. J. (1960a). N.Z. vet. Y. 8, 4.

Drake, C., Grant, A. B. \& Hartley, W. J. $(1960 b)$. N.Z. vet. F. 8, 7.

Goldschmidt, V. M. (1954). Geochemistry. Oxford: The Clarendon Press.

Hartley, W. J. \& Grant, A. B. (I96I). Fed. Proc. 20, 679.

Jolly, R. D. (1960). N.Z. vet. F. 8, i I.

McLean, J. W., Thompson, G. G. \& Claxton, J. H. (1959). N.Z. vet. F. 7, 47.

Marr, T. G., Sharman, G. A. M. \& Blaxter, K. L. (1956). Vet. Rec. 68, 408.

Muth, O. H., Oldfield, J. E., Remmert, L. F. \& Schubert, J. R. (1958). Science, 128, 1090.

Muth, O. H., Oldfield, J. E., Schubert, J. R. \& Remmert, L. F. (1959). Amer. Э. vet. Res. 20,23 I.

Nisbet, D. I., Butler, E. J. \& Macintyre, I. J. (1959). F. comp. Path. 69, 339.

Patterson, E. L., Milstrey, R. \& Stokstad, E. L. R. (1957). Proc. Soc. exp. Biol., N.Y., 95, 6I7.

Proctor, J. F., Hogue, D. E. \& Warner, R. G. (1958). F. Anim. Sci. 17, 1183.

Rankama, K. \& Sahama, T. G. (1950). Geochemistry. University of Chicago Press.

Schubert, J. R., Muth, O. H., Oldfield, J. E. \& Remmert, L. F. (1961). Fed. Proc. 20, 689.

Schwarz, K. \& Foltz, C. M. (1957). F. Amer. chem. Soc. 79, 3292.

Sharman, G. A. M., Blaxter, K. L. \& Wilson, R. S. (1959). Vet. Rec. 71, 536.

Stamp, J. T. (1960). F. comp. Path. 70, 296. 